\title{
Discussion on Financing Strategy Management of Mature SMEs
}

\author{
Wei Deng
}

Business College, University of Science and Technology of Wuchang, Wuhan Hubei, 430223, China

Key words: Mature, SME, Financing strategy, Management.

\begin{abstract}
Since China joined WTO, small and medium enterprises (SMEs) in China have entered a new development stage. In current stage, SMEs have entered the mature process, thus called mature SMEs. The growth rate will be tend to be mild and stable. Meanwhile, the operational risk of SMEs will lower. According to current situation, most mature SMEs have numerous problems, mainly including poor competitiveness, lack of standardization in management and insufficient capital etc. These problems seriously hinder the development of mature SMEs. In such an important period, financing strategy management of mature SMEs is an effective way to help enterprises solve problems. On this basis, the author deeply discusses financing strategy management of mature SMEs.
\end{abstract}

\section{Introduction}

After SMEs enter the mature period, enterprises have owned sufficient credit standing and respectability, and their ability to bear financial risks will change. This contributes to banks to loan, and issue bonds or stocks. However, the problem faced by SMEs is to how to invest in new production line. This is a very important constituent part in enterprises' overall development strategy and belongs to enterprises' financing strategy. To improve financing efficiency, it is necessary to analyze the influence of various strategic elements.

\section{Management form and risks of mature SMEs}

\section{Management form of mature SMEs}

As enterprises grow and expand the scale, legal form of mature SMEs is presented in the form of corporate system $^{[1]}$. Corporate system belongs to essential feature scope of modern enterprise system. Some mature enterprises will adopt the form of joint-stock company in order to maintain their development and raise funds through going public. Some enterprises with large scale and strong strength will adopt the form of company limited by shares tp improve enterprise image and financing ability. Once an enterprise enters the mature period, it needs to change product development strategy. It is difficult for old enterprise products to help enterprises continue development. Only development of alternative products or diversified investment can stop an enterprise from declining. As a typical organization structure of diversified enterprises, if the organization structure of business department changes, it will leads to profound influence on enterprises' management control system, innovation and objective. As for he importance of business department, it can improve enterprises' financing efficiency $^{[2]}$. Meanwhile, it makes enterprises' investment path no longer single and becomes more diversified. In addition, since human is a basic element of organization structure, personnel policy in an organization also has certain influence on enterprises' financing strategy and financing capacity.

\section{Financing risks of mature SMEs}

The omen for an enterprise to enter the mature period is aggressive price competition among competitors. When SMEs develop to the peak, this means they turn to mature enterprises. In this period, SMEs have improved significantly in terms of technology and product scale. In this way, large quantities of positive cash flow will appear. The operational risk in this period has tended to be steady or been in the decrease stage. Product life cycle is limited. In this period, enterprises' strategic decision should focus on how to extend the life cycle of main products and extend enterprise brand life. To guarantee healthy and sustainable development of enterprises, it is also necessary to develop 
new products in good time. Therefore, strategic decision of mature SMEs is very important. In this period, operational risk of SMEs is related to enterprise management level. After long-term development, SMEs have established various management systems, and its information disclosure capacity is also strong. Thus, enterprise information is more transparent ${ }^{[3]}$. From legal perspective, regardless of SMEs which go public and non-listed enterprises, their operation information and financial information are clear and convenient for audit. In such situation, information risk of external investors will not be too high,

\section{FRICT financing decision-making method}

In FRICT, F is Flexibility; $\mathrm{R}$ is risk; $\mathrm{I}$ is Income; $\mathrm{C}$ is Control; $\mathrm{T}$ is Timing. FRICT financing decision-making method refers to 5 thoughts of enterprise financing ${ }^{[4]}$. For enterprises, the components of their capital structure are very diversified due to the composition of capital source and proportion difference. After enterprises enter the mature period, financing channels of SMEs present the feature of diversification, while corresponding enterprise capital structure also needs changes. To look for an optimal capital structure, it is required to confirm whether the capital source of SMEs is stable. In current stage, for financing structure selection of SMEs, they should first analyze financial indexes. On this basis, the qualitative method should be applied to formulate the capital structure objective which is most beneficial to sustainable development. In this process, other some factors should be considered, such as overall strategy, financial institution, development speed, earning power and earning power. Since mature SMEs have superior conditions, they own numerous financing options. In such circumstance, enterprises need to take into account of capital expansion mode and capital expansion efficiency. Thus, enterprises should prudently choose financing mode. In general, financing management objective of SMEs lies in improving financing efficiency and meeting enterprises' strategic requirements. Just because of this, FRICT financing analysis method may be selected to achieve financing management objective. Under certain conditions, enterprises apply various financing tools to determine strategic management method of financing decision-making in a short time, i.e. FRICT financing decision-making method. In FRICT financing decision-making method, Flexibility represents the possibility of financing channel options and more possibilities of financing options. It is used to analyze enterprises' credit orientation, and the possibility public bond or equity market financing. Meanwhile, it is also used to analyze whether the capital source influences financial flexibility. Risk represents the ability to bear financial risk, i.e. enterprises' ability to bear financial risk after a series of factors such as operational risk, business strategy, asset and income situations are considered comprehensively. Income represents the changes in income, earnings per share, interest, dividend distribution and cash flow after a financing way is chosen, i.e. variation trend of market profit and stock rice of enterprise competitors on even ground. Control represents the function of contract articles on the creditor when debt financing is taken into account, where the creditor's control of enterprise is mainly considered. Timing represents the opportunity of grasping and selecting financing tools. The most optimized financing tool can make current capital structure closer to the optimal capital structure fast. In terms of capital source, more attractive capital source should be chosen after current economic condition and capital market situation are considered.

\section{Financing channels of mature SMEs}

\section{Depreciation-based financing}

Depreciation-based financing is one of financing channels of mature SMEs. Depreciation represents calculation and collection of enterprise cost and expense, while depreciation-based financing is achieved through this process ${ }^{[5]}$. Besides, depreciation represents recovery of fixed asset value of an enterprise. For mature enterprises, depreciation-based financing is an appropriate choice, because all kinds of conditions of mature SMEs are sufficient. If enterprises choose depreciation-based financing, 
they can not just avoid cost waste, but also need not undertake too high risks. These advantages contribute to optimization of financing structure. In the rapid development period, most enterprises choose depreciation-based financing and regard it as the capital source. According to current development situation of China, there is still huge space for SMEs in China to choose depreciation-based financing.

\section{Finance-based financing}

Finance-based financing is another financing channel of mature SMEs. If mature SMEs choose finance-based financing, they need the help of financial institutions to achieve financing purpose. Financial institutions have close cooperation relationship with enterprises, so they can provide credit funds and assist enterprises in implementing financing strategy. Usually, finance-based financing has fixed and explicit sources. To be more specific, the following items are included: (1ppolicy bank; (2) commercial bank; (3)credit funds of non-bank financial institution; (4) financing lease of leasing company. Finance-based financing have both advantages and disadvantages. For mature SMEs, finance-based financing has significant advantages in terms of financing scale and financing form. In this way, enterprises do not get involved in stock rights. But, the threshold of finance-based financing is high, i.e. high financing conditions and financing cost. Therefore, SMEs suitable for finance-based financing generally conform the following conditions: (1) enterprises' product market is mature; (2) enterprises develop rapidly; (3) enterprises' strength is strong; (4) enterprises' technology is advanced; (5) enterprises' internal funds are short (temporary). For mature SMEs, external financing channel is the major mode, and it can help mature SMEs continue to develop. This has been verified by the development of SMEs in Japan. In one word, enterprises must be prudent when choosing finance-based financing channel as the major financing channel, because they need to face the financing influence brought by high financial risk and high remuneration.

\section{Security-based financing}

Security-based financing is one of financing channels of mature SMEs. With this financing mode, enterprises raise funds from the society through all kinds of negotiable securities and enter the securities market to publicly issue stocks. SMEs in China now lack strength. But, this purpose can be achieved through other ways, such as internal employee holding shares or counterparty holding shares.

\section{Joint financing}

Joint financing is one of financing channels of mature SMEs. This financing is accomplished through taking full advantage of capital strength of other enterprises. In the financing process, business credit financing (accounts payable, notes payable and advance on sales) will be involved. The financing may be implemented through alliance, absorption, merger and investment etc. credit financing can solve the problem of insufficient circulating funds.

\section{Financing strategy management of mature SMEs}

\section{Scale expansion investment}

If SMEs choose scale expansion investment strategy, they need to expand sales scale of core products. This investment strategy belongs to a common investment strategy of mature SMEs. Scale expansion investment strategy has practical significance and contributes to rapid development of SMEs. To achieve this objective, two paths can be chosen: 1) market penetration; 2) product development strategy. The first path expands sales volume of products and market share through increasing market share of existing products and the quantity of products on the market. Seeing from current product market situation, market share has been basically saturated. Thus, it is necessary to find out another way and launch the products on other regions. The investment objects should focus on raw materials and accessories as well as talent development. In other words, it is necessary to pay attention to 
investment in the development of internal resources. There are two applicative conditions for market penetration and development strategy: 1) life cycle of enterprises' core products is in the special stage (problem product stage, star product stage); 2) market demand tends to be steady. When market penetration and development strategy are applied, many risks are inevitable. Besides, the application of market penetration and development strategy is to the disadvantage of enterprises to choose better investment opportunities. Meanwhile, compared with large enterprises, most SMEs are significantly insufficient in some aspects, mainly reflected in new market development fund and technical ability.

\section{Stable investment}

Manure SMEs are faced with such plight that although they have strong growth will, their internal conditions and abilities are limited. Thus, they cannot take large risks in terms of financial management, but need to come down to earth. In the process of seeking development, mature SMEs are always faced with failure. The reason for this consequence is very significant, i.e. unsteady financial management. Unsteady financial management is reflected in two aspects. On the one hand, the proportion of working capital used for fixed asset investment is too large. After the development for some time, SMEs have owned good resources and can gain fat profits in the booming market. In such condition, SMEs will relax vigilance on turnover of vigilant, which creates an environment for expanding fixed asset investment. The consequence is non-flexible turnover of working capital. On the other hand, investment purpose is not strong, and the investment is too disperse. In the development process of SMEs, diversified investment and diversified operation are required for product diversification in order to reduce operational risk. Although investment diversification can avoid operational risk, enterprises also bear corresponding consequence, i.e. the profit of original operating items declines. Besides, investment diversification is quite adverse to the development of SMEs. Small overall investment scale results in non-flexible turnover of working capital for original operating items, and enterprises have insufficient operation ability and management experience for new investment projects. Thus, they have no competitiveness.

\section{Conclusion}

In conclusion, for SMEs, the state has issued some rules and regulations as well as some methods to encourage financing of SMEs to assist their development in current stage. These policies and schemes help enterprises to go through dome difficulties to some extent. Seeing from the difficulties of SMEs in financing and gaining loans, this has become the primary cause of hindering the development of SMEs. In order to relieve the difficulty of SMEs in financing, it is required to discuss financing strategy management of mature SMEs, take into account of management form and risk of mature SMEs, analyze FRICT financing decision-making method and financing channels of SMEs and help mature SMEs choose suitable financing channels.

\section{References}

[1] Shen Jishan, Analysis of financing strategy management of mature SMEs, Intelligence, 2011,02:25.

[2] Zhao Jingkun, Analysis of financial strategy of SMEs in mature period, Cooperative Economy \& Science, 2011,18:80-81.

[3] Zhou Fahe, On financial strategyselection of SMEs, Brand (II), 2012,11:29-30.

[4] huang Tianjiao, Study on capital operation risk of innovative SMEs in each growing stage, Business Economy, 2015,03:84-86.

[5] Ying Xiaofeng, Influence of network development of technology-based SMEs on their financing, Pioneering with Science \& Technology Monthly, 2010,08:31-33. 